\title{
X: 151608808-151605221
}

National Cancer Institute

\section{Source}

National Cancer Institute. X: 151608808-151605221. NCI Thesaurus. Code C45155.

Physical location of MAGEA3_Gene 